Language Teaching

http://journals.cambridge.org/LTA

Additional services for Language Teaching:

language

teaching

Email alerts: $\underline{\text { Click here }}$

Subscriptions: Click here

Commercial reprints: Click here

Terms of use : $\underline{\text { Click here }}$

\title{
AlLA Africa Research Network Launch 2007: Research into the use of the African languages for academic purposes
}

Rosemary Wildsmith-Cromarty

Language Teaching / Volume 42 / Issue 01 / January 2009, pp 131 - 134

DOI: 10.1017/S0261444808005454, Published online: 22 December 2008

Link to this article: http://journals.cambridge.org/abstract_S0261444808005454

How to cite this article:

Rosemary Wildsmith-Cromarty (2009). AILA Africa Research Network Launch 2007: Research into the use of the African languages for academic purposes. Language Teaching, 42, pp 131-134 doi:10.1017/S0261444808005454

Request Permissions : $\underline{\text { Click here }}$ 


\title{
Research in Progress
}

\section{AILA Africa Research Network Launch 2007: Research into the use of the African languages for academic purposes}

\author{
University of the Witwatersrand, Johannesburg, South Africa, 30 June 2007
}

The aim of the one-day symposium was to bring together scholars in applied linguistics with an interest in the African languages for the launch of the new AILA Africa regional network. Contributions were in the form of invited research papers from several African countries. This report focuses on the South African contribution, which highlighted current research into the use and development of the African languages for academic purposes in response to the South African National Language Education Policy (South Africa, DoE 2002) with its focus on the development of multilingualism in the country.

This report highlights various projects that were initiated in response to the goals set by the Language Education Policy, and underpinned by research indicating a relationship between a sound home language base, the development of English proficiency and the acquisition of academic subject matter (including technological and scientific) at both secondary and tertiary educational levels. With reference to technological and scientific domains in particular, knowledge has been imported from the West without any adaptation to or integration with indigenous social practices and language usage (Prah 1996). There is thus a need for participatory development involving the cooperation and feedback of the target groups whose languages are the focus of this research.

Key questions surrounding the development, promotion and use of African languages in education include the following:

(i) What is the nature of current didactic practices in the learning and teaching of the African languages at school and tertiary levels?

(ii) What is the impact of these didactic practices on learners' literacy levels, and their proficiency in, acceptance and use of the standard varieties of the African languages as tools for learning?

(iii) What is the current level of learners' and teachers' academic proficiency in the African languages? Is it sufficient to access subject content through the medium of an African language?

(iv) What should drive language development - corpus or acquisition planning?

The projects address these questions, focusing on teaching the African languages; using them as support to facilitate understanding of concepts in subject matter presented in English; facilitating their acquisition in academic domains by using them as languages of instruction and focusing on the development of specialized terminology.

The Home Language Project (HLP) was initiated in 2001 by the school governing bodies of six English-medium schools in Johannesburg (Rodseth \& Rodseth 2004). It aims to provide 
cost-effective home language maintenance for the African language learners enrolled at these schools, especially where the full range of indigenous languages are represented. In addition to the home language development program which teaches both Nguni- and Sothobased languages, the Project also provides a Reading Program and library service in all nine indigenous languages, and also uses bilingual materials to teach mathematical concepts and language. The project has succeeded in changing the learners' attitudes towards their languages as useful tools for learning school subjects.

A second project operating at secondary level is the Concept Literacy Project (CLP), which involves the Universities of Cape Town, KwaZulu-Natal and Rhodes. This study seeks to provide home language support (isiZulu, isiXhosa and Afrikaans) for Mathematics and Science teachers at secondary schools (Grades 7-12) in the form of a multilingual Resource Book which provides a textual resource base of mother tongue equivalents for English medium core concepts for Mathematics and Science (Young 2005). Findings from classroom observations and interviews with teachers highlighted the problem of unfamiliar terminology coined by the translators, where borrowings might have been more useful for clarifying concepts (Wildsmith \& Gordon 2006).

At tertiary level, the Bilingual Education component in the Foundation Year program for Maths and the Sciences at the University of Pretoria also uses bilingual material to teach concepts in Mathematics and Science, drawing on research and development of scientific terms, particularly for physics and chemistry (Pare 2006). Because they had mostly studied the subject matter through English, students preferred bilingual materials to monolingual materials in the local languages, which they found difficult to understand, again pointing to the need for 'community' participation in language development.

The Bilingual Degree program at the University of Limpopo is one of the first initiatives of its kind to transfer resources from the English language to an African language. The Project aims to develop knowledge of both English and an African language to a high degree of academic proficiency by offering two majors: Multilingual Studies offered in Northern Sotho, and Contemporary English Language Studies, offered in English. It is based on the belief that using the African languages as already sufficient languages of instruction can drive the development of terms for scientific/specialized concepts (Ramani et al. 2007).

Findings from the above initiatives are mixed. The HLP and Bilingual degree program in Limpopo have achieved measurable success in terms of increased proficiency in the African languages and increased enrolments for the degree program. These projects were driven by conceptual and communicative needs (Ramani et al. 2007) at grassroots level. The CLP has enjoyed a positive response from teachers, although there were problems with the imposition of unfamiliar terminology. Findings from the bilingual project at the University of Pretoria, however, are not as positive, as less than 3\% of students expressed interest in studying physics through the medium of the home language. Apart from negative student attitudes towards the use of the home languages as instructional languages, the issue of translatability across languages, especially those non-cognate with English, and the related issue of terminology development are not unproblematic. There have been a number of initiatives working on this aspect of African language development since 2005.

At the University of Pretoria, various projects focus on standardization, translation and development of terminology (Webb 2007). Themes include language standardization versus 
the linguistic realities of the varieties used in classrooms in the Tshwane area, including code-mixing; examining the impact of translated Grade 12 examination papers on learners' performance; the production of dictionaries and standardized terminology lists for specialized and technical discourse, examples being an English-Northern Sotho dictionary in Industrial Electronics and a terminology list of basic chemistry terms in Northern Sotho and isiZulu, and the testing of the use of the Force Concept Inventory, a standardized physics test, translated into the home languages. Findings from these projects highlight problems of term creation and conceptual equivalence in back translation (Webb 2007).

A comparable initiative, arising out of the work of the Technical Sub-Committee of the English National Language Body and subsequently funded by the National Research Foundation, is an investigation into the translatability of academic discourse across languages, specifically in relation to Mathematics and the Natural Sciences (Wildsmith-Cromarty 2008). The languages selected for translation and analysis were isiZulu, SeSotho and Setswana. The study worked with twenty translators drawn from three provinces where the languages were represented. Preliminary findings confirm the existence of lexical 'gaps' across languages, with non-equivalence also operating at the syntactic level. Translation strategies used to address these problems included word-coinage, borrowings or paraphrase. What has become evident from this study is the need for wider consultation, cooperation and networking among the various language bodies tasked with such development, and the end-users. In relation to reference works, there is a need for clear discriminators in dictionaries which summarize the main uses of a word, its field and collocations. Following from this, an appropriate lexicon needs to be developed for use in schools and universities, adequately contextualized and standardized across regions.

The projects focusing on standardizing the African languages and term creation for concept development (corpus planning) did not enjoy as much success as those focusing on the use of the languages driving their own development (acquisition planning). The latter highlight the importance of the use of participatory methods when developing terms in a language. The projects also highlight the need for a focus on bilingual and multilingual language learning in teacher education programs. This should be the main focus of future research in the country.

\section{References}

Pare, P. (2006). The use of local African languages as languages of science. Presented at the SAARMSTE conference, July 2006, University of Pretoria.

Prah, K. K. (1996). The language factor in the scientific and technological development of Africa. Presented at the Human Sciences Research Council, Pretoria, March 1996. In H. Griesel (eds.), The feasibility of technical language development in the African languages. Pretoria: Department of Arts, Culture, Science and Technology/National Terminology Services, 21-38.

Ramani, E., T. Kekana, M. Modiba \& M. Joseph (2007). Terminology development versus concept development through discourse: Insights from a dual-medium BA degree. Southern African Linguistics and Applied Language Studies 25.2, 207-221.

Rodseth, W. \& V. Rodseth (2004). Developments in the Home Language Project since SAALA 2002. Presented at the International SAALA Conference on Multilingualism, July 2004, University of the North, Limpopo.

South Africa, Department of Education (DoE) (2002). National Language Policy for Higher Education. Pretoria.

Young, D. N. (2005). A Guide to the CALLSSA Concept Literacy Project and its implementation in 2005 (Project document). University of Cape Town. 
Webb, V. (2007). Research projects on the sociolinguistic development of African languages at the University of Pretoria. Presented at the Joint Annual LSSA/SAALA conference, July 2007, University of the North-West, Potchefstroom.

Wildsmith, R. \& M. Gordon (2006). The role of the L1 in learning Mathematics and Science concepts. Presented at the Joint Annual LSSA/SAALA conference, July 2006, University of KwaZulu-Natal.

Wildsmith-Cromarty, R. (2008). Can academic/scientific discourse really be translated across English and African languages? Southern African Linguistics and Applied Language Studies 26.1, 147-169.

Rosemary Wildsmith-Cromarty

University of KwaZulu-Natal South Africa

WildsmithR@ukzn.ac.za 